\title{
Amelioration of Urban Temperature through Landscape Design Approaching Hot-Humid Climate: A review
}

\author{
Sharifah Khalizah Syed Othman Thani, \\ Nik Hanita Nik Mohamad, Sabrina Idilfitri \\ Department of Landscape Architecture, Faculty of Architecture, Planning and Surveying, \\ Universiti Teknologi MARA, Malaysia \\ khalizah81@gmail.com
}

\begin{abstract}
This paper discusses a conceptual review of sustainable landscape design approach as mitigating strategies to modify urban temperature in a hot- humid climate. The amelioration of urban temperature through landscape approach can be achieved by incorporating sustainable landscape design practices via the interplay of natural vegetation in the hot-humid tropics. The findings of this paper are hoped to guide the practitioners in landscape architecture, policy makers and urban designers to incorporate sustainable landscape design approach towards improving outdoor thermal comfort; thus providing a better quality of life.

Keywords: Landscape design principles; outdoor thermal comfort; urban heat island; hot-humid climate

eISSN 2514-751X @ 2018. The Authors. Published for AMER ABRA CE-Bs by e-International Publishing House, Ltd., UK. This is an open-access article under the CC BY-NC-ND license (http://creativecommons.org/licenses/bync-nd/4.0/). Peer-review under responsibility of AMER (Association of Malaysian Environment-Behaviour Researchers), ABRA (Association of Behavioural Researchers on Asians) and CE-Bs (Centre for EnvironmentBehaviour Studies), Faculty of Architecture, Planning \& Surveying, Universiti Teknologi MARA, Malaysia. https://doi.org/10.21834/aje-bs.v3i8.274
\end{abstract}




\subsection{Introduction}

The issue on urban heating due to the occurrence of Urban Heat Island (UHI) phenomenon in hot-humid climate has received tremendous attention among climatologists and urban designers recently. Due to this phenomenon, urban dwellers experienced intense urban heating that caused thermal discomfort to do activities in an outdoor environment.

As a region that are close to the equator, the hot-humid climate generally experiencing averagely a uniform temperature, high humidity, high intensity of solar radiation and low wind velocity all year round. These features make it as the biggest challenge for practitioners in urban planning and design to integrate climate-responsive elements into the design.

However, at the age of global warming and climate change, prudent task should be taken in improving current urban climatic condition to safeguard sustainability of urban ecosystems in the future. Due to its ability to interact between built and natural elements; as well as an interdisciplinary profession, hence, landscape architects have a huge potential to modify the effects of extreme climatic conditions (Brown, 2011) through adoption of environmentallyresponsive design that incorporate bioclimatic aspects to outdoor environments. In this paper, we concisely describe a holistic approach on landscape principles considering the needs for both at regional and micro scale; in the context of humid tropics. This paper attempts to deduce from the literature review of selected journals on climate modification through urban and landscape design approaches. Therefore, the emphasis is made on method used by previous researchers.

\subsection{Effects of Urban Heat Island (Uhi) to the Urban Landscape of Hot-Humid Climate}

A large body of literature observed that the occurrence of UHI phenomenon has resulted undesirable effects to the urban climate. Unlike several temperate countries where UHI effect is somehow demonstrated as thermal benefit during the winter season (Grimmond etal, 2010; Givoni, 1998:256), the hot-humid climate is on the contrary.

Few tropical studies have shown that generally daytime $\mathrm{UHI}$ is more pronounced than nocturnal UHI. This is because, due to high solar absorption in the daytime, the building structures and urban impervious surfaces tend to store heat where it has increased the urban temperature. However, the natural landscape of hot-humid tropics that surrounded by the abundance of tropical rainforest should be utilised to offer shading and evaporative cooling towards providing thermal advantage (Grimmond et al., 2010). It is observed that some of the tropical trees like Messuaferrea (Ironwood tree) and Hurracrepitans (Indonesian Umbrella Tree) can attenuate solar radiation almost $92.55 \%$ and $79 \%$ respectively (Shahidan et al., 2010), thus lowering ground surface temperature by reducing the amount of terrestrial radiation underneath the canopy.

\subsection{Design Consideration of the Urban Landscape In Hot-Humid Climate} Mitigation strategies to reduce the effects of urban heat through proper planning of 
landscape design and utilisation of natural vegetation have received growing interest among both researchers and tropical urban landscape designers recently. Due to its ability to improve urban temperature without earning higher cost (Sandifer, 2009), the utilisation of natural vegetation can play a role as passive elements in design (Yeang, 2006). In addition, the modification of urban temperature by landscape design approach can be implemented from the regional to the local or micro scale (Brown, 2011), thus, make it the most comprehensive mitigating approach to reduce heat island effects.

In general, climatic factors that affect outdoor thermal comfort are (1) surface and air temperature; (2) relative humidity; (3) solar radiation; and (4) wind velocity. Previous studies in temperate countries have shown that there is significant climate modification through design recommendations (Brown, 2011). However, the requirement is someway vice versa for tropics.

In particular to hot-humid climatic zones, many researchers (Grimmond et al., 2010; Yeang, 2006; Emmanuel, 2005; Givoni, 1998) agreed that solar shading is the most crucial requirement to be incorporated in to the design. Hence, the aim to minimise heat gain and cover urban surface as much as possible through solar shading should be the first priority in the urban landscape design of tropical climate (Figure 1).

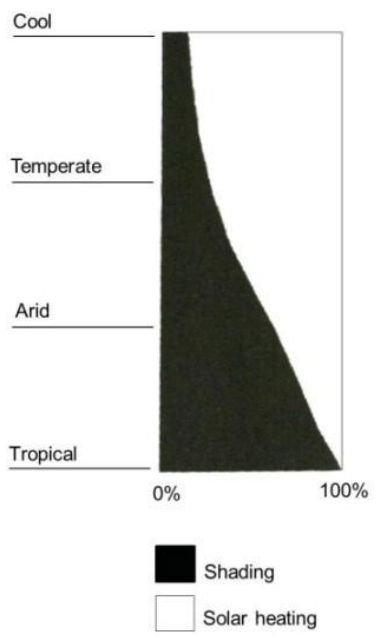

Fig. 1: Theneedfor solar shadingincreasesinthetropical climaticzones

(Source: Yeang, 2006)

Another requirement is a modification of urban ventilation by promoting wind velocity and to directingit to the necessary area (Givoni, 1998: 260-261; Wirdoyo, 2008). As humid tropics experienced light winds, the landscape approach should considerproper designs that allow optimum ventilation (Emmanuel, 2005:115-118;Givoni, 1998: 293-297). Whilst tropical trees and vegetation is significantly a greater shadow provider by minimisingsolar infiltration 
when configured in a large number, nevertheless, it is to be carefully designed in order to promote urban ventilation of humid tropics. This is because, the density tends to obstruct wind velocity and intensify relative humidity where it should be avoided in hot-humid climate; as it will disrupting user's thermal comfort (Hidayat, 2010; Wirdoyo, 2008).

\subsection{Regional-scale (Site Planning)}

The augmentation of cooling potential in larger scale needed in contributing to the urban thermal modification. Design implication is at the early stage of urban and landscape planning where it should consider spatial planning of all natural landscape units and human aspects (Selman, 2006) especially for a new development; by linking the landscape and climate of locality.

\subsection{The Master Plan}

A holistic approach must aim to facilitate the development into a regional model of a climatesensitive city as its primary objective. This can be done by integrating the whole aspects of urban ecosystems consisting of biotic and abiotic component and the association with architectural concepts. Figure 2 shows the paradigm of climate-sensitive urban landscape planning.

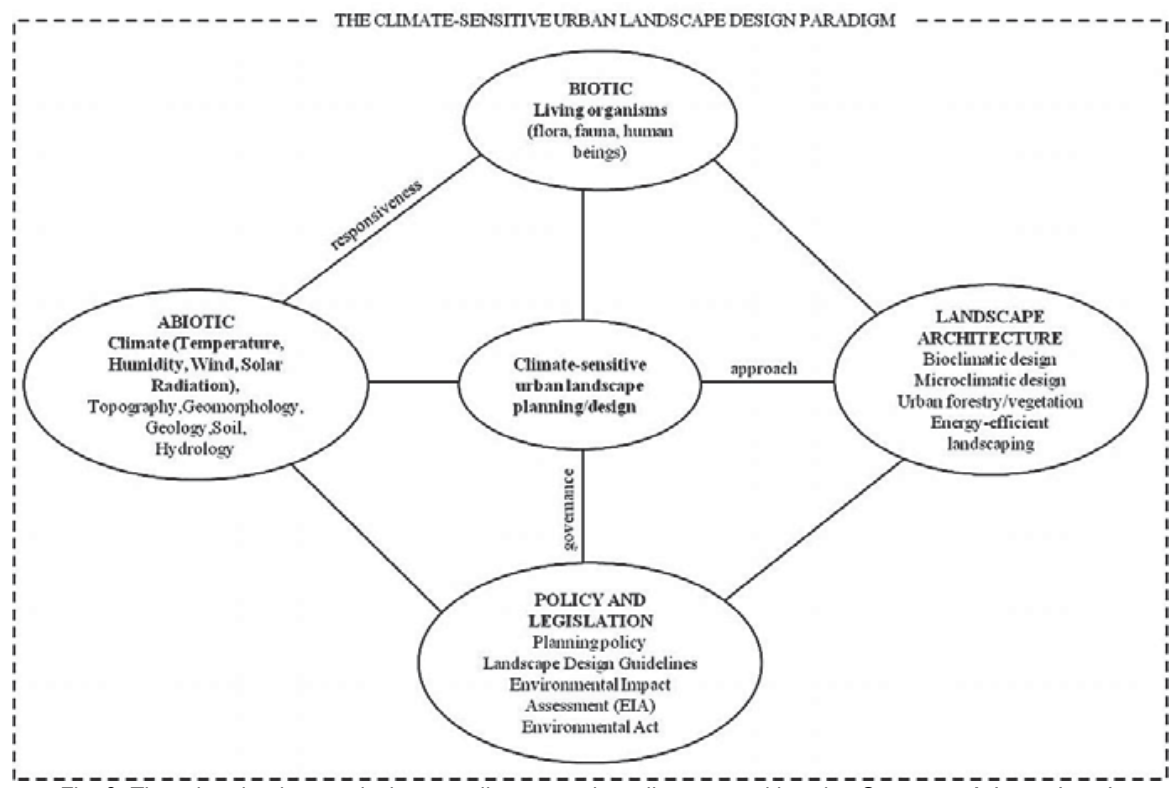

Fig. 2. The urban landscape design paradigm towards a climate-sensitive city; Sources: Adapted and modified from Selman (2006).

In order to design a climate-sensitive city, the development must endeavour to 
accommodate the adoption of environmentally-responsive design that integrates bioclimatic aspects to outdoor environments; due to its strong relationship with climate, nature and living environment. But what considered as bioclimatic component in landscape design? Numerous researchers suggest that the intensive and extensive use of natural vegetation and urban greenery, body of water elements and landscape design structures in response with climatic variability is implicitly the bioclimatic approach in the urban landscape.

A study inthe hot-arid environment by Attia (2009) endorsed the Bioclimatic-Zones Concept through landscape design strategy in site planning. The concept contemplating the use of landscape elements such as vegetation;light structures and water elements as passive design strategy in creating bioclimatic zones. Through this concept, it is fulfilling the desired climatic modification by a group of design decisions and provides a roadmap for landscape practitioners to leverage several related guidelines. Furthermore, the uses of natural resources like vegetation and water bodies contributes to the urban thermal improvement from cooling- island effect, more ecologically sound and promote pleasant living environment through climate adaptation (Sun and Chen, 2012).

\subsection{Policy and Legislative Dimension}

To encourage good stewardship and responsible use of natural resources, it requires pertinent execution by policy and legislation. Basically, it should be applied as part of the decision-making process in the provision of urban planning stage (Eliasson, 2000). In the planning phase, environmentally sensitive area like forest and natural water body as bioclimatic component should be determined. Its development should be conducted as stipulated in the Environmental Quality Act and follow Environmental Impact Assessment (EIA) regulations (Shaharuddin et al., 2009). By reason to incorporate the importance of climatic aspects in long- term planning considerations, the enclosure of local climate impact in the EIA check list should be proposed (Eliasson, 2000).

The existing urban planning policy and design guidelines should also be revised and amended to the current environmental demands. For instance, the gazette amount of green areas in current urban planning guidelines should ensure that it is sufficient to cater the needs for cooling purposes. Other than that, towards ensuring climate-resilience development at national level, government should embarking the incentives through income tax deduction and stamp duty exemption for the building owners who obtained Green Building Index (GBI) certification, and for every development on green technology.

\subsection{Micro-scale (Site Design)}

The design intervention is taking into consideration for detailed- design, redesigning purposes or adaptive design to the existing outdoor urban environment by intention to improve microclimatic condition.

\subsection{Vegetation and Planting Design Scheme}

The role of vegetation in microclimatic design strategy are varies and can be applied in the building-scale, street level or urban and semi- urban level (Wirdoyo, 2008; Yeang, 2006). 
From the benefitsof its evapotranspiration process and morphological characteristics, trees can be manipulated as a great climatic moderator. The use of vegetation can contribute to many thermal benefits like providing shade effect, lowering ground and air temperature, reduced solar infiltration, ventilation effect and minimise glare from reflection (Hidayat, 2010; Wirdoyo, 2008). In designing urban spaces with vegetation, requirements that should be consider arethe selection of appropriate plant materials, configuration of tree planting and nativity of urban space.

As hot-humid tropics mainly required shading and solar filtration, Shahidan et al. (2010/2011) and Hidayat (2010) pointed out that selection of plant species should focused on tall (evergreen) trees with width canopy, massive leaves (Leaf Area Index (LAl) value >5) and dense branches to filter radiation. Besides, the landscapeatmosphere of planting area should also be considered since this will ensure the effectiveness of thermal improvement. According to Hidayat (2010), the survival and ability of plants to associate with its atmosphere depends on the nativity and attribute of the area. However, specifically for modification of thermal environment, the appropriate amount of green spaces has to be in the right proportioned to counterbalance urban impervious area as to ensure the efficiency of vegetative cooling.

Few studies in hot-humid tropical cities revealed that urban greenery has many positive impacts in moderating urban climate. It shows that an area planted with dense vegetation could averagely reduce 4 to $5^{\circ} \mathrm{C}$ of urban temperature in the hot afternoon. Larger green area with judicious trees demonstrated stronger cooling effects than the smaller ones. Besides, short vegetation like shrubs and grass also helps in modifying urban temperature through its evaporative mechanism.In conclusion, selection of vegetation should consider more native and ecologically restorative and choice of species should reflects the bioclimatic requirements.

\subsection{Water Elements}

There are growing interestsobserved on the design mechanism of water bodies as climatic regulator among urban designers. This is due to its cooling and thermal stabilizer effects in an urban environment (Sun and Chen, 2012). The significance of water bodies for urban climate modification includes its influence on transformation of latent and sensible heat fluxes, an "oasis effects"by its evaporation and reduced surface temperature of its surrounding (Sun and Chen, 2012).According to Sun and Chen (2012), the mean temperature of water bodies was $29.49^{\circ} \mathrm{C}$, which is lower by temperature ranging of $0.58^{\circ} \mathrm{C}-3.37^{\circ} \mathrm{C}$ than the green land $\left(30.07^{\circ} \mathrm{C}\right)$ and built-up area $\left(32.86^{\circ} \mathrm{C}\right)$.

The design strategy for water bodies in hot regions is to provide as many as possible "wet surfaces" as evaporation surface for cooling effects to the nearby surrounding. The cooling effects of water bodies depend to its physical environment; for instance, in downtown areas with dense built-up characteristics, the ambient temperature of water may increase as it absorb more sensible heat (Sun and Chen, 2012). Hence, if water bodies can be positioned to take advantage of air movement patterns at a local scale and planting 
trees around water bodies, the contiguous environment can naturally be "conditioned" to increase cooling potential of air (Emmanuel, 2005: 133).

It is found that the geometry or shape as well as depth of water bodies had impacts to the variations of Urban Cool Island ( $\mathrm{UCl}$ ) intensity but negatively correlated to $\mathrm{UCl}$ efficiency of water body area (Sun and Chen, 2012). This means that more small water bodies can offer similar beneficial effects as the same total area of water bodies. It is also observed that shape and depth of water bodies has less significant impact to the cooling potential of the urban environment rather than the influences of the surrounding landscape. Therefore, the varying ability of cooling effects depends on the proportions of water body area and the threshold with landscape environments.

\subsection{Energy-efficient Landscape Approach}

Energy-efficient landscape approach can be described as building- scale design intervention intended to improves the energy use of a building where vegetation serves as passive means for minimising temperatures around buildings as well as reducing overall UHI (Yeang, 2006: 224). Although it is at building-scale effects, however, when implemented on a larger scale, it can gives multiplier effects to the urban cooling efforts. What constitute energy-efficient landscaping? According to Yeang (2006: 140), it encompass any kind of accessible areas in built forms that noticeably available forintegration with vegetation.

\subsubsection{Vertical landscaping:}

Shading of exterior tall building surfaces and openings by façade planting (Figure 3) gives thermal comfort advantages for both indoor and outdoor spaces. Landscape design elements like shade trees, green wall and vines on trellis and pergolas attached close to building plays an important role as it dissipates heat from building skin and improve microclimate adjacent to buildings (Sandifer, 2009). A field tests on the use of pergola covered by vines by Sandifer (2009) determined that vines grown directly on pergolas or walls with thickness of 12-14 inches can reduce the surface heating of built forms and provide exterior comfort at nearby area of the buildings. Besides, it is also helps in reducing glare from solar reflection and increase user's visual comfort.

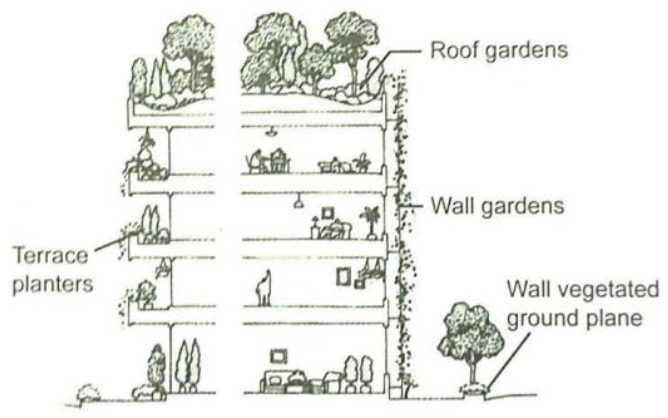

Fig. 3: Vertical planting design. Source; Yeang, (2006) 


\subsubsection{Green roof (vegetated roof):}

In term of climate control, rooftop vegetation can be as effective as ground vegetation as it provides hospitable environment for plant life.In fact, their evaporative cooling potential could be more significant because it is exposed closer to the sun and wind at these areas (Yeang, 2006: 140-141). Indeed, green roofs can also function as passive cooling elements by its potential of energy saving. Other than urban cooling, rooftop vegetation also benefited as storm water reduction (Shaharuddin et al., 2009) removal of air pollution and promotes urban biodiversity.

Table 1 summarises the synthesis of literature review regarding temperature modification in urban areas through landscape approaches. It is outlining thestrategies, considerations and design implications underlying the concept taken from the findings of the previous authors.

Table 1. Synthesis of literature overview on landscape design approaches toward modification of hot urban thermal environment

\begin{tabular}{|c|c|c|c|c|c|c|c|c|}
\hline $\begin{array}{l}\text { Stage of } \\
\text { decision }\end{array}$ & Scale & Citation & $\begin{array}{l}\text { Research } \\
\text { concen }\end{array}$ & Design objectire & Design strategies & $\begin{array}{l}\text { Desimn } \\
\text { consideration }\end{array}$ & Findings & Designimplication \\
\hline \multirow[t]{4}{*}{ Plaming } & \multirow[t]{4}{*}{$\begin{array}{l}\text { Regional- } \\
\text { scale }\end{array}$} & $\begin{array}{l}\text { Hiddayat } \\
(2010) \\
\text { Wirdoyo } \\
(2008)\end{array}$ & $\begin{array}{l}\text { Benefits of } \\
\text { urbant trees in } \\
\text { improxing } \\
\text { urban } \\
\text { microdimate }\end{array}$ & $\begin{array}{l}\text { Uiban regetation } \\
\text { to control the } \\
\text { increasing of } \\
\text { temperature and } \\
\text { urban heat island }\end{array}$ & $\begin{array}{l}\text { Gremery in tem } \\
\text { of parks, green } \\
\text { networks (street } \\
\text { planting, } \\
\text { greenbelts etc.) }\end{array}$ & $\begin{array}{l}\text { Size of green } \\
\text { areas, tipes of } \\
\text { regetation, parts } \\
\text { corerage and } \\
\text { built-up } \\
\text { proportions }\end{array}$ & $\begin{array}{l}\text { Larger green covereage } \\
\text { areas demonstrated } \\
\text { siguificant temperature } \\
\text { feduction tegardless of } \\
\text { time }\end{array}$ & $\begin{array}{l}\text { Urban vegetation prove the } \\
\text { effectiveness in reducing } \\
\text { urban temperature and } \\
\text { upgrade enviroumental } \\
\text { quality }\end{array}$ \\
\hline & & $\begin{array}{l}\text { Attia (2009), } \\
\text { Sandiffer } \\
\text { (2009), }\end{array}$ & $\begin{array}{l}\text { Biodimatic } \\
\text { potential in } \\
\text { urban cooling }\end{array}$ & $\begin{array}{l}\text { Biodimatic } \\
\text { components in } \\
\text { fulfiling the } \\
\text { desired dimatic } \\
\text { improvement }\end{array}$ & $\begin{array}{l}\text { Biodimatic- } \\
\text { zones concept by } \\
\text { utilising } \\
\text { landscape } \\
\text { principles }\end{array}$ & $\begin{array}{l}\text { Appropiate } \\
\text { desimn decision } \\
\text { for climatic } \\
\text { improvement at } \\
\text { each bioclimatic- } \\
\text { zones }\end{array}$ & $\begin{array}{l}\text { Desired dimate } \\
\text { improvement depends on } \\
\text { indiridual role of } \\
\text { bioclimatic approach. }\end{array}$ & $\begin{array}{l}\text { Biodimatic landscape } \\
\text { approch helps in site } \\
\text { plammingto to mprove } \\
\text { mirodimate of outdoor } \\
\text { areas }\end{array}$ \\
\hline & & $\begin{array}{l}\text { Shahandddin } \\
\text { et al.(2009), } \\
\text { Eliasson } \\
(2000)\end{array}$ & $\begin{array}{l}\text { Policy and } \\
\text { legisilation }\end{array}$ & $\begin{array}{l}\text { Awrareness } \\
\text { towrads } \\
\text { association of } \\
\text { dimate } \\
\text { moowledge in } \\
\text { planning }\end{array}$ & $\begin{array}{l}\text { Requirement of } \\
\text { green areas } \\
\text { conserration and } \\
\text { dimate chechlist } \\
\text { to incoporatein } \\
\text { EIA }\end{array}$ & $\begin{array}{l}\text { Preservation of } \\
\text { enriroumentally- } \\
\text { sensitive area in } \\
\text { urban plannigg } \\
\text { stage and } \\
\text { dimatic nules in } \\
\text { EIA }\end{array}$ & $\begin{array}{l}\text { Currentplanning } \\
\text { guiddlimes should be } \\
\text { rexised to meet the needs } \\
\text { of changing themal } \\
\text { enviroument and secure } \\
\text { sustaimabledesign } \\
\text { practices }\end{array}$ & $\begin{array}{l}\text { Climate lnowledge and } \\
\text { guidelimes should be } \\
\text { leverage by relerant parties } \\
\text { to ensure sustainable } \\
\text { practices in urban planning }\end{array}$ \\
\hline & & $\begin{array}{l}\text { Shahididan and } \\
\text { Jones (2008) }\end{array}$ & $\begin{array}{l}\text { Optimising } \\
\text { plant canopy } \\
\text { structurefor } \\
\text { shadimg and } \\
\text { radiation } \\
\text { filtration }\end{array}$ & $\begin{array}{l}\text { Evaporation of } \\
\text { latent-heat and } \\
\text { solar shading by } \\
\text { utilisimg structure } \\
\text { of plant canopies }\end{array}$ & $\begin{array}{l}\text { Plant canopy } \\
\text { design }\end{array}$ & $\begin{array}{l}\text { Characteristics } \\
\text { that provide } \\
\text { optimum } \\
\text { filtration, shadimg } \\
\text { and temperature } \\
\text { reduction } \\
\text { undemeath tree } \\
\text { canopy }\end{array}$ & $\begin{array}{l}\text { Variations of canopy } \\
\text { densities modify solar } \\
\text { radiation, shading ground } \\
\text { surface and promote } \\
\text { eraporative cooling that } \\
\text { help reducing } \\
\text { surrounding temperature. }\end{array}$ & $\begin{array}{l}\text { Improxisation of planting } \\
\text { schemes and plant canopy } \\
\text { desigap potentially modify } \\
\text { microclimate and promote } \\
\text { urban thermal comfort }\end{array}$ \\
\hline
\end{tabular}


Syed Othman Thani, S.K., et.al. / Asian Journal of Environment-Behaviour Studies (ajE-Bs), 3(8) May / Jun 2018 (p1-11)

\begin{tabular}{|c|c|c|c|c|c|c|c|c|}
\hline \multirow[t]{4}{*}{$\begin{array}{l}\text { Design } \\
\text { phase } \\
\text { (Site } \\
\text { design) }\end{array}$} & \multirow[t]{4}{*}{$\begin{array}{l}\text { Micro- } \\
\text { scala }\end{array}$} & $\begin{array}{l}\text { Shahidan etsl } \\
(2010)\end{array}$ & $\begin{array}{l}\text { Trea spacies } \\
\text { that effectively } \\
\text { create shade and } \\
\text { modify } \\
\text { radiation }\end{array}$ & $\begin{array}{l}\text { Improving human } \\
\text { thermal comfort } \\
\text { through shada } \\
\text { creation and } \\
\text { radiation } \\
\text { modification }\end{array}$ & $\begin{array}{l}\text { Utilisation of } \\
\text { plantmorpholog } \\
\text { and species } \\
\text { characteristics }\end{array}$ & $\begin{array}{l}\text { Shade creation } \\
\text { and radistion } \\
\text { control by trea } \\
\text { canopy and } \\
\text { foligge gaometry } \\
\text {-effectiveness of } \\
\text { Mesuaferea L. } \\
\text { and Hura } \\
\text { crepitans L. }\end{array}$ & $\begin{array}{l}\text { Mfenrea L is more } \\
\text { effective in reducing } \\
\text { thermal radiation and } \\
\text { potentially creates cool } \\
\text { island effects when } \\
\text { planting in large number. } \\
\text { H.crepitans L. is } \\
\text { moderately reduced } \\
\text { radiation but suitable for } \\
\text { planting in open spaces } \\
\text { dua to its wider shade. }\end{array}$ & $\begin{array}{l}\text { Using appropriste plant } \\
\text { species with suitabla } \\
\text { characteristics halps in } \\
\text { providing optimum solas } \\
\text { shading and radiation } \\
\text { filtration }\end{array}$ \\
\hline & & $\begin{array}{l}\text { Sandifer } \\
(2009), \\
\text { Yeang } \\
(2006),\end{array}$ & $\begin{array}{l}\text { Green roof as } \\
\text { passive } \\
\text { elements in } \\
\text { energy saving } \\
\text { and } \\
\text { microclimatic } \\
\text { improvement }\end{array}$ & $\begin{array}{l}\text { Conversion of } \\
\text { conventionsl } \\
\text { rooftop to grean } \\
\text { roofs to improve } \\
\text { microclimate and } \\
\text { reduce building } \\
\text { energy use }\end{array}$ & $\begin{array}{l}\text { Grean roofl } \\
\text { rooftop } \\
\text { vegatation }\end{array}$ & $\begin{array}{l}\text { Typas of } \\
\text { vegatation, } \\
\text { adaptation of } \\
\text { plant at rooftop } \\
\text { atmosphere }\end{array}$ & $\begin{array}{l}\text { Grean roofs significantly } \\
\text { raduce air temperature as } \\
\text { and energy use by urben } \\
\text { built forms as compresed } \\
\text { to concrete roof }\end{array}$ & $\begin{array}{l}\text { Grean roofs capable for } \\
\text { coolingambient tir } \\
\text { temperature similarlylike } \\
\text { ground vegegtation. } \\
\text { Additionally, it is usefil as } \\
\text { storm water reduction and } \\
\text { help to promote urhen } \\
\text { biodiversity }\end{array}$ \\
\hline & & $\begin{array}{l}\text { Sandifer } \\
(2009) \text {, } \\
\text { Yeang (2006) }\end{array}$ & $\begin{array}{l}\text { Vertical } \\
\text { landscaping }\end{array}$ & $\begin{array}{l}\text { Effectivenass of } \\
\text { vines shading and } \\
\text { façade planting in } \\
\text { reducing surface } \\
\text { temperature of } \\
\text { build forms }\end{array}$ & $\begin{array}{l}\text { Façada } \\
\text { plantingivinas } \\
\text { shading }\end{array}$ & $\begin{array}{l}\text { Vinas on } \\
\text { trellis/vegetation } \\
\text { wall }\end{array}$ & $\begin{array}{l}\text { A vinas covered } \\
\text { pergola'wall or facade } \\
\text { planting can modify } \\
\text { surfaca temperature, } \\
\text { shade glazed openings } \\
\text { and provide outdoor } \\
\text { comfort to area adjacent } \\
\text { to buildings }\end{array}$ & $\begin{array}{l}\text { Plants near building' } \\
\text { vegatated walls lower } \\
\text { ambient air temperature and } \\
\text { can be energy-efficient } \\
\text { landscapingmathodin } \\
\text { reducing energy use of tha } \\
\text { building. Create exterior } \\
\text { and interior cooling } \\
\text { comfort. }\end{array}$ \\
\hline & & $\begin{array}{l}\text { Sun and Chan } \\
\text { (2012) }\end{array}$ & $\begin{array}{l}\text { Climate } \\
\text { adaptation of } \\
\text { urban water } \\
\text { bodies }\end{array}$ & $\begin{array}{l}\text { Coolingisland } \\
\text { effects/intensity } \\
\text { of water bodies by } \\
\text { evaporative } \\
\text { cooling }\end{array}$ & $\begin{array}{l}\text { Placement of } \\
\text { water bodies in } \\
\text { urban } \\
\text { environment }\end{array}$ & $\begin{array}{l}\text { Location, } \\
\text { geometry, } \\
\text { nativity of water } \\
\text { body's areasnd } \\
\text { surrounding } \\
\text { built-up } \\
\text { proportions }\end{array}$ & $\begin{array}{l}\text { Variations of Urban Cool } \\
\text { Island (UCI) intensity and } \\
\text { efficiency had low impact } \\
\text { to its gavomatry but } \\
\text { significantly depanding } \\
\text { between tha covergage of } \\
\text { water bodies and its } \\
\text { surrounding landscapa }\end{array}$ & $\begin{array}{l}\text { Varying ability of cooling } \\
\text { effects depends on the } \\
\text { proportions of water body } \\
\text { grea and the threshold with } \\
\text { landscape environments }\end{array}$ \\
\hline
\end{tabular}

\subsection{Design Challenges and Constraints}

\subsection{Use of Natural Elements}

Although vegetation is the excellent climate moderator, nonetheless, as a natural element, it should be noted that their capabilities to execute as climate regulatorare closely related to the adaptability with the physical environment (Hidayat, 2010). Factors like growth rate, interaction with other species in plant community, air quality and environmental surrounding play a bigger role in determine capability and survival of the vegetation.

The use of water elements should also bemeticulously designed to meet climatic needs of a certain area. The geometry, hydrological aspects, location and the surrounding landscapes influences the evaporative cooling potential of water bodies (Sun and Chen, 2012). It should be noted that only sufficient amount of water body coverage should be taken into design to optimise its evaporation rate,and to avoid excessive humidity in ambient temperatureof hot-humid tropics (Emmanuel, 2005: 132-133) as it has a probability to lower user's thermal comfort. 


\subsection{Policy and Legislation}

According to Eliasson (2000), integration of climate knowledge in the planning process had little impact. Due to this matter, it is least cooperation from related authorities regarding the use of climatic aspects in urban planning. Furthermore, lack of enforcement through policy also caused the authorities turned to other things that deemed higher priority rather than climate-sensitive urban planning. Hence, the designer-friendly tools (Brown, 2011; Eliasson, 2000) as integrated strategy of delivering climate data must be developed between urban climatologist, planners and decision-makers in order to guide practitioners and professionals towards the effectiveness of climate-design intervention.

\subsection{Conclusion}

This paper provides useful information for practitioners in landscape architecture about the climate- sensitive and environmentally-responsive approach in urban planning through landscape principles. In response to the improvement of urban climatic condition, we need to revised current urban planning and design methods by considering the needs to adapt the changing climate and interrelationship between the design elements with the desired climatic impact. Despite all advantages of landscape design approach, one should carefully design to specific needs of a particular area depends on its local climate and microclimate regime. Thus, this requires landscape planners and architects to have an in-depth understanding on the climatic needs of a particular area. The approach to modify urban temperature depends on climatic requirement of particular area; where different places, different approach.

Mitigating strategies through design seems to be best option as it is interim adaptive response to accommodate not only climate-related issues but also to many of environmental problems. By manipulating design intervention and scientific elements of landscape knowledge, solid mitigation approach could be achieved. Though, the efforts in creating thermal comfort environment are not under the jurisdiction of planners and designers only but it is an interdisciplinary approach that needs breadth cooperation with other related parties.

\section{Acknowledgement}

This research paper is supported by a grant of Research Intensive Faculty (RIF) from Research Management Institute (RMI), Universiti Teknologi MARA (600RMI/DANA/5/3/RIF(111/2012).

\section{References}

Attia, S., 2009. The Bioclimatic Zones Concept: Landscape Design Strategy for Site Planning in HotArid Climate. Smartand Sustainable Built Environment, 2009 (SASBE2009).

Brown, R.D., 2011. Ameliorating the effects of climate change: Modifying microclimates through design. Journal of 
Syed Othman Thani, S.K., et.al. / Asian Journal of Environment-Behaviour Studies (ajE-Bs), 3(8) May / Jun 2018 (p1-11)

Landscape Urban Plan. (2011), doi: 10.1016/j.landurbplan.2011.01.010

Eliasson I., 2000. The use of climate knowledge in urban planning. Landscape and Urban Planning Journal 2000;48:31-44.

Emmanuel, M.R., 2005. An Urban Approach to Climate-Sensitive Design: Strategies for the tropics. Spon Press, New York. 63-89

Givoni, B., 1998. Clima te Considerations in Building and Urban Design.John Wiley and Sons Inc.pp. 256

Grimmond C.S.B., Roth M., Oke T.R., Au Y.C., Best M., Betts R., Carmichael G., Cleugh H., Dabberdt W., Emmanuel R., Freitas E., Fortuniak K., Hanna S., Klein P., Kalkestein L.S., Liu C.H., Nickson A., Pearlmutter D., Sailor D. and Voogt J., 2010. Climate and More Sustainable Cities: Climate Information for Improved Planning and Management of Cities (Producers/Capabilities Perspectives). Procedia Environmental Sciences 1 (2010) 247-274.

Hidayat, I.W., 2010, The Ecological Role of Trees and their Interactions in Forming the Microclimate Amenity of Environment, Jurnal Bumi Lestari, Volume 10 No. 2, Augustus 2010, hlm. 182-190.

Sandifer, S.A., 2009. Using the Landscape for Passive Cooling and Bioclimatic Control:Applications for higher density and larger scale. 26th Conference on Passive and Low Energy Architecture, Quebec City, Canada, 22-24 June 2009

Selman, P., 2006. Planning at the Landscape Scale. Routledge, Taylors and Francis Group. London and New York.

Shaharuddin, A., Noorazuan, M.H., Yaakob, M.J., 2009. Fenomena Pulau Haba Bandar dan isu alam sekitar di Bandaraya Kuala Lumpur. In Malay. GEOGRAFIA Online ${ }^{T M}$ Malaysian Journal of Society and and Space 5 Issue 3. pp 57-67 